\title{
Marketing channels and constraints in stall fed and grazing methods of sheep and goat rearing in Dharwad district
}

\author{
B. Priyanka and C. Murthy
}

Received : 26.07.2019; Revised : 05.09.2019; Accepted : 20.09.2019

\begin{abstract}
The present study was conducted in Dharwad district 2018-19. The multistage random sampling technique was selected for the study. For the study, 2 taluks of Dharwad district namely, Dharwad and Navalgund taluk were purposively selected to throw light on the study. These 2 taluks have highest number of sheep and goat population and stall fed units in the study area. From each taluk, 8 villages with highest population of sheep and goat and 3 stall fed units and from each village 5 sheep and goat rearing farmers were selected randomly for the study. For obtaining information related to marketing of sheep and goat, 5 village merchant, 5 wholesalers and 5 retailers (butchers) were selected. The price spread was lowest in channel-III (butcher) due to the absence of more number of market intermediaries in marketing of sheep and goat. High cost of shed construction was found to be the major constraint in the stall fed rearing and shrinkage of grazing land in case of grazing method of sheep and goat rearing.
\end{abstract}

KEY WORDS : Marketing channels, Intermediaries, Producer's share in consumer's rupee, Price spread, Consumer purchase price, Shrinkage of grazing land, Kidding

How to cite this paper : Priyanka, B. and Murthy, C. (2019). Marketing channels and constraints in stall fed and grazing methods of sheep and goat rearing in Dharwad district. Internat. J. Com. \& Bus. Manage, 12(2) : 52-57, DOI: 10.15740/HAS/IJCBM/12.2/52-57. Copyright@ 2019: Hind Agri-Horticultural Society. 